\title{
Effects of grazing on orthopteran assemblages of Central-European sand grasslands
}

\author{
ZOLTÁN KENYERES'
}

1 Acrida Conservational Research L.P., Tapolca 8300, Hungary.

Corresponding author: Zoltán Kenyeres (kenyeres@acridabt.hu)

Academic editor: Corinna S. Bazelet | Received 12 June 2017 | Accepted 14 January 2018 | Published 12 June 2018

http://zoobank.org/931577F0-49AA-4CA9-965A-E2A5FB862ECC

Citation: Kenyeres Z (2018) Effects of grazing on orthopteran assemblages of Central-European sand grasslands. Journal of Orthoptera Research 27(1): 23-33. https://doi.org/10.3897/jor.27.15033

\begin{abstract}
The effect of grazing on Orthoptera assemblages has long been the focus of research worldwide due to the high sensitivity of orthopterans to changes in vegetation structure. According to previous studies, grazing has individual, spatially-different effects on orthopteran assemblages. The current case study was carried out between 2012 and 2016 in a subarea dominated by open sandy grasslands in the Carpathian Basin. The 70 ha study area was grazed by $250-300$ sheep in 2012. In the beginning of 2014, the overgrazing pressure was overall reduced, for the most part, in the examined grassland patches. The study aimed to answer how the complete abandonment of grazing and moderate grazing influences the species richness, diversity and density of the orthopteran assemblages. Investigations in Central European sand steppes confirmed that both intense grazing and the abandonment of grazing have a detrimental effect on the structure of orthopteran assemblages: (a) the Shannon diversity index was higher on moderately grazed sites than on grazed and ungrazed ones; (b) the number of habitat specialists of sandy grasslands was higher on moderately grazed patches than in grazed habitats; and (c) the frequency of geophilic species was higher on grazed patches than on moderately grazed and grazing-abandoned ones.
\end{abstract}

\section{Key words}

density, diversity, Hungary, land use intensity, sheep, vegetation structure

\section{Introduction}

The structure of habitats and their insect communities exposed to direct and indirect human impact usually can be considered a transient state (Pickett et al. 1992). This phenomenon can be well observed in grazed grasslands where current vegetation structure, as a background factor to the insect communities, is highly influenced by the intensity, spatial and temporal characteristics and abandonment of grazing (Carboni et al. 2015, Török et al. 2016). Both the vertical and horizontal structure of vegetation, through the removal of the biomass and through trampling, are changed by grazing (Asner et al. 2004). Intensive grazing ( overgrazing) in grasslands usually results in decreased plant diversity, the invasion of some grazing-tolerant plant species, and the overall degradation of the habitat-structure (Metera et al. 2010). Nutrient-poor habitats seem to be the most sensitive to grazing intensity (Kruess and Tscharntke 2002). When the grazing pressure decreases or is abandoned in the grasslands of a temperate climate zone, the coverage of the dominant, narrow-leaved perennial monocotyledons of the associated plants increases (Critchley et al. 2008), while the coverage of annual plant species becomes reduced (Matus et al. 2003). In addition to the favorable changes for the vegetation-dependent insect communities, the abandonment of grazing can also cause the invasion of weeds in the grasslands (Sedláková and Fiala 2001). This usually greatly decreases the presence of rare and threatened Orthoptera (Fonderflick et al. 2014). Therefore, in the habitats grazed traditionally, the maintenance of extensive grazing is a prerequisite for preserving biodiversity (Dolek and Geyer 2002) and seems to be far more suitable than mowing (Weiss et al. 2013).

The high sensitivity of orthopterans to a change in vegetation structure is well known (Báldi and Kisbenedek 1997, Samways 1997, Gardiner et al. 2002, Bazelet and Samways 2011, Weiss et al. 2013). Based on this, the effect of grazing on orthopteran assemblages has been the focus of research worldwide and for a long time (e.g. White 1975, Jepson-Innes and Bock 1989, Prendini et al. 1996, Kruess and Tscharntke 2002, Jauregui et al. 2008, Gardiner and Haines 2008, Zhu et al. 2015). Grazing results in individual, spatially different effects on the orthopterans. Some studies, for example, revealed lower orthopteran density in grazed grasslands than in ungrazed ones (Welch et al. 1991, Onsager 2000), while in other cases the opposite was found (Wingerden et al. 1991). These differences are likely to be due to not only the habitat-dependent effects of the grazing, but also to species-specific responses (O'Neill et al. 2003, Jauregui et al. 2008) of orthopterans to intensity (Kruess and Tscharntke 2002, Cease et al. 2012), timing (Fonderflick et al. 2014) and livestock type (Dolek and Geyer 2002) of grazing. Most of the results of the assessment of the impact of grazing suggest that, according to the intermediatedisturbance hypothesis of Connell (1978), orthopteran assemblages show the largest diversity in moderately grazed grasslands (Batáry et al. 2007, Fabriciusová et al. 2011, Jerrentrup et al. 2014).

My study area is situated between the Danube and the Tisza rivers in the Carpathian Basin in the eastern half of Central-Europe, 
where the dominant vegetation type is the Pannonian sand steppe occurring in Europe only in the Pannonian biogeographical region (6260 Pannonian sand steppes, 2002/83/EC Habitat Directive). Due to the conditions of the almost humus-less bedrock (sand), the structure and species composition of the habitats could remain potentially unchanged even for centuries in the absence of any interventions. However, grazing has been present in the area since, most likely, the Neolithic (Molnár et al. 2008), so for several thousand years. Thus, large herbivores played a role in the development of the actual state of the grasslands (Máté 2014). In the 16-17th century, extensive grazing was carried out on a large area of the region - mainly with cattle and, to a lesser extent, with sheep (Frisnyák et al. 2015). After the beginning of the 18th century, afforestation was carried out for the purpose of impeding erosion and for utilizing areas unsuitable for agricultural use (mainly Pinus sylvestris and Robinia pseudo-acacia were planted). As a result, the extent of areas covered by forests increased from 3.5\% to 60\% (Molnár 2003). However, some hills covered by open sandy grasslands remained, and until the middle of the 20th century they were grazed by the sheep of small farmers (Kun 1998). In the past decades and even now, grazing, especially sheep-grazing, was concentrated in small areas. The dominance of sheep grazing affected, among other things, the Fabaceae plant species of the sandstone pastures and their associated animal species, resulting in the decline or extinction of a number of plant species at the beginning of the 19th century (Máté 2014).

In addition to the above historical landscape characteristics, responses of the orthopteran assemblages associated with the typical habitats of the Central European sand steppes were affected by several local and global factors. From a local point of view, it can be said that the orthopteran assemblages of Central European habitats grazed with different intensity have not yet been sufficiently investigated. Certainly, in regards to the long-term effects of the various types of grazing, and the long-term effects of the abandonment of grazing, there are several questions to be answered. Several further questions remain to be answered both locally and globally with regards to quality and intensity of grazing being adequate for the most diverse and dense orthopteran assemblages (Jerrentrup et al. 2014).

The main questions of the present investigation were the following: 1) How does the complete abandonment of grazing or moderate grazing influence the species richness, diversity and density of orthopteran assemblages in grasslands that were heavily overgrazed at the beginning of the study? 2) Is the span of the study (from 2012 to 2016) enough to detect changes in the structure of orthopteran assemblages occurring in sandy grasslands characterized by low plant production? 3) How does the drastic decrease of grazing pressure impact the density of local populations of habitat-specific species?

\section{Material and methods}

Study area.-The study area is part of the Natura 2000 site Kékhegyi lötér (HUKN22037; southern Hungary) (Fig. 1). It is located at an altitude of $\sim 160 \mathrm{~m}$ a.s.l. and is characterized by flat, low sandy hills and flatlands. The average total duration of annual insolation in the region is 2,055 hours. Mean annual temperature is around $10.6^{\circ} \mathrm{C}$. The mean values of absolute maximum and minimum temperatures are $34.7^{\circ} \mathrm{C}$ and $-16.4^{\circ} \mathrm{C}$. The average annual precipitation is $570 \mathrm{~mm}$ (330 $\mathrm{mm}$ in the growing season) (Dövényi 2010). The study area is characterized by sandy soils. Based on analyses of Szilard Szabó (pers. comm.), mean of the main soil parameters of the local grasslands are the following: $\mathrm{CaCO}_{3}$

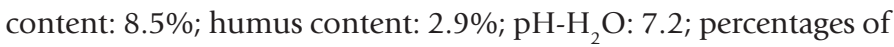
the soil fractions: rough: $0.2 \%$; middle-class: $9.7 \%$; small: $80.6 \%$; mud: $7.1 \%$; loam: $2.3 \%$.

Land use.-Based on the first known detailed map of the study area, in the 18th century the typical land use of the open sandy grasslands studied was grazing (http://mapire.eu/hu/map/firstsurvey). In the 19th and 20th centuries some places in the area were afforested, but the main form of land use on the grasslands was still grazing (see http://mapire.eu/hu/map/secondsurvey; http://mapire.eu/ hu/map/hkf_25e; http://mapire.eu/hu/map/hungary1941). After World War II the area was used as a closed military base, but the grazing of sheep continued. When military operations ceased in 1990 , the grazing of sheep became increasingly intense. The $~ 70$ ha study area was grazed by 250-300 sheep in 2012. The overgrazing pressure was overall reduced in the majority of the study area in the beginning of 2014 in order to conserve nature.

Experimental design. - Six sampling sites were established, as 50×50 m sized quadrats. Data collection was carried out from 2012 to 2016. One site was on a place ungrazed during the study (Ungrazed - U-G), three sites were located in places on which grazing pressure was reduced to zero at the beginning of 2014 (Grazing Abandoned - G-A), two sites were located in places on which grazing pressure was reduced to a moderate level (Moderately Grazed - M-G) (Fig. 1). Sites were considered to be "grazed" (Grazed - G) prior to 2014 and the reduction of grazing pressure.

Vegetation and landscape structure.-Measurements of the vegetation parameters were carried out on 3 plots in each sampling site of each orthopteran sampling. The following parameters were recorded: total vegetation cover (\%), average height of the vegetation $(\mathrm{cm})$, and bare soil (\%). Height of the vegetation was measured in $\mathrm{cm}$ with the use of a $30 \mathrm{~cm}$ wide and $100 \mathrm{~cm}$ high white card. Total cover of the vegetation was measured in a square meter quadrat occurring around the spot. Related to each orthopteran sampling, percentage cover of plant species was estimated. Annual means of the measured parameters per sampling sites were calculated.

Orthoptera.-During each of the five study years, sampling of the Orthoptera took place in June, July, and August. In every period, 2 samplings were carried out by sweep-netting on random patches of each sampling site (altogether 180 samples). Within the $50 \times$ $50 \mathrm{~m}$ sized sites, the samplings took place at least $30 \mathrm{~m}$ from each other. Densities were recorded in $10 \times 10 \mathrm{~m}$ quadrats with 300 sweeps per sample and were completed by direct observations. To the samples collected by sweep netting I added a simple count of the number of adult specimens which were detected by direct observation/collection. Sweep-netted samples were identified to species level using the works of Harz (1969, 1975). Acrida ungarica (Herbst), Acrotylus insubricus (Scopoli), Acrotylus longipes (Charpentier), Calliptamus barbarus (Costa), Celes variabilis (Pallas), Dociostaurus brevicollis (Eversmann), Euchorthippus pulvinatus (Fischer de Waldheim), Gampsocleis glabra (Herbst), Montana montana (Kollar), Myrmeleotettix maculatus (Thunberg), Oedaleus decorus (Germar), Omocestus minutus (Brullé), Platycleis affinis Fieber, Sphingonotus caerulans (Linnaeus), Stenobothrus fischeri (Eversmann) were classified as habitat specialists of local sandy grasslands. Scientific nomenclature follows Cigliano et al. (2017).

Categories of Uvarov (1977), Ingrisch and Köhler (1998) and Krištín et al. (2009) were used for classification of life forms (arboricol: species found in habitats dominated by tree-sized elements; ar- 

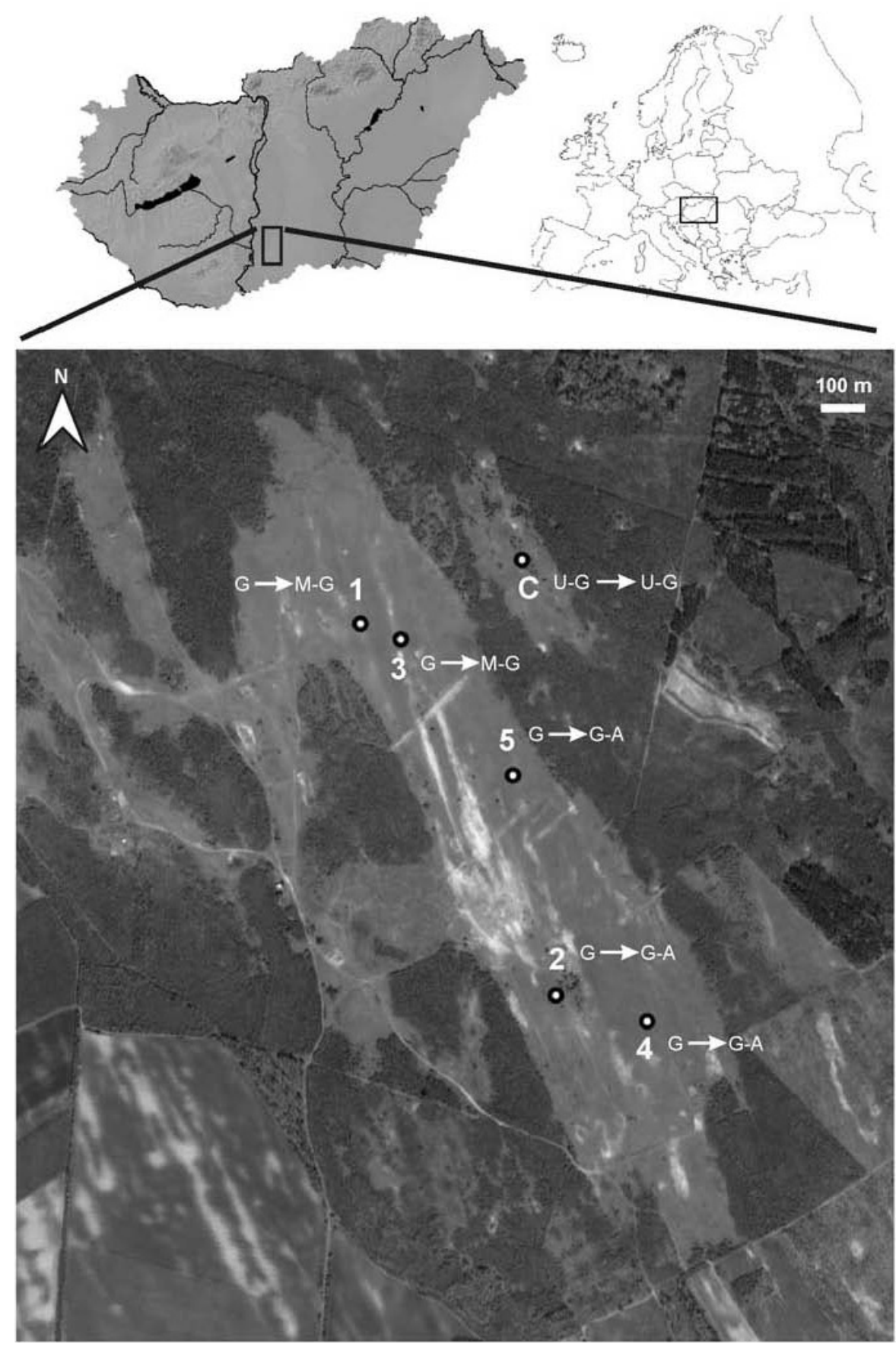

Fig. 1. Location and land use-changes of the studied sites (G: grazed; G-A: grazing-abandoned; M-G: moderately grazed; U-G: ungrazed). Letters to the left of the arrow indicate land use in 2012 and 2013; letters to the right of the arrow indicate land use in 2014, 2015 and 2016.

busticol: species found in habitats dominated by shrub-sized items; silvicol: species found in forest habitats with a grass understory; pratinicol: species found in grasslands of tall grass; graminicol: species found in grasslands of short grass; geophilic: species found in grasslands characterized by a high percentage of bare soil; psammophilic: species found in sandy grasslands; pseudo-psammophilic: species found mainly in sandy grasslands, but also in grasslands occurring on soil very similar to sand, e.g. dolomite rendzina).

Characterization of climatic requirements of the species as thermophilic, moderately-thermophilic, mesophilic, moderately- hygrophilic, and hygrophilic were assigned based on the works of Varga (1997), Rácz (1998), and Ingrisch and Köhler (1998).

Statistical analysis. - Samples collected in the same sampling sites in the same year were pooled (number of pooled samples was 30: Ungrazed - U-G n = 5; Grazing Abandoned - G-A n = 9; Moderately Grazed - M-G n = 6; Grazed - G n = 10). Pooled samples were used for calculating assemblage variables and statistical analyses. Shannon diversity index, species richness, density (individual $/ 10 \mathrm{~m}^{2}$ ), species number and relative frequencies 
of habitat specialist species, relative frequencies of geophilic and graminicol/pratinicol species were calculated and used as Orthoptera response variables in statistical analyses. Mean values $( \pm S E)$ of Orthoptera response variables were calculated for comparison of structure of orthopteran assemblages exposed to different grazing pressure. Mann-Whitney U test was used to evaluate statistical differences among the derived orthopteran variables. Orthoptera samples were ordered by PCoA (similarity index: correlation, relative frequency data of species were used and subtract mean transformed). Generalized linear models (Poisson distribution; response variables: relative frequencies of geophilic and graminicol/pratinicol species; predictor variables: total vegetation cover, average height of the grass, bare soil) were performed. CCA ordination based on Orthoptera species data and environmental parameters (total vegetation cover, percentage of bare soil, height of the vegetation) were also compiled. All statistical analyses were performed by using Past 3.14. software package (Hammer et al. 2001).

\section{Results}

Orthoptera diversity and density.-Thirty-five Orthoptera species (Appendix 1) comprising 2,655 individuals were recorded on 6 sampling sites. The most prevalent species was Calliptamus barbarus with 580 individuals (24\%), followed by Acrida ungarica with 514 individuals (19\%), Euchorthippus declivus (Brisout de Barneville) with 302 individuals (11\%), Oedaleus decorus with 279 individuals (10\%), Oedipoda caerulescens (Linnaeus) with 210 individuals (8\%), Myrmeleotettix maculatus with 185 individuals (7\%), Dociostaurus brevicollis with 117 individuals (4\%), Euchorthippus pulvinatus with 54 individuals (2\%) and Omocestus petraeus (Brisout de Barneville) with 52 individuals (2\%). Shannon diversity, more sensitive to rare species (Magurran 2004), was highest on moderately grazed sampling sites, and this parameter was lower and similar to each other on grazed, grazing-abandoned and ungrazed sampling sites (Mann-Whitney test: $\mathrm{U}_{\mathrm{G}-\mathrm{MG}}=7, \mathrm{p}=0.014 ; \mathrm{U}_{\mathrm{MG}-\mathrm{UG}}=$ $0, \mathrm{p}=0.008$; Fig. 2). Species richness was non-significantly higher in moderately grazed and grazing-abandoned grasslands, than on grazed and ungrazed patches (Fig. 2). Overall, Orthoptera density was higher on the ungrazed patches than on moderately grazed and grazing-abandoned ones $\left(\mathrm{U}_{\mathrm{MG}-\mathrm{UG}}=1, \mathrm{p}=0.013 ; \mathrm{U}_{\mathrm{GA}-\mathrm{UG}}=5, \mathrm{p}=\right.$ 0.023 ) and non-significantly higher than on grazed ones (Fig. 2).

Composition of Orthoptera assemblages.-PCoA ordination showed separation of orthopteran assemblages under different grazing pressure. Sites grouped according to whether they were ungrazed, grazing-abandoned/moderately-grazed or grazed (Fig. 3). The number of habitat specialist species was significantly higher on moderately-grazed patches than on grazed ones $\left(U_{M G-G}=13.5, p=\right.$ 0.05 ) and that parameter was non-significantly higher on grazingabandoned and ungrazed patches than on grazed sites (Fig. 4). The number of habitat specialist species was as high on grazingabandoned sites than on the ungrazed site. The frequency of habitat specialist species did not show decided differences related to grazing pressure (Fig. 4). The frequency of geophilic species was significantly higher on grazed sites than on moderately-grazed and grazing-abandoned ones $\left(\mathrm{U}_{\mathrm{G}-\mathrm{MG}}=9, \mathrm{p}=0.026 ; \mathrm{U}_{\mathrm{G}-\mathrm{GA}}=15, \mathrm{p}=\right.$ $0.015)$. Furthermore, the above mentioned parameter was significantly higher on ungrazed sites than on moderately-grazed ones $\left(\mathrm{U}_{\mathrm{UG}-\mathrm{MG}}=4, \mathrm{p}=0.050\right)$ (Fig. 5). Parallel to the latter results, the frequency of graminicol/pratinicol species was significantly lower on grazed sites than on moderately-grazed and grazing-abandoned
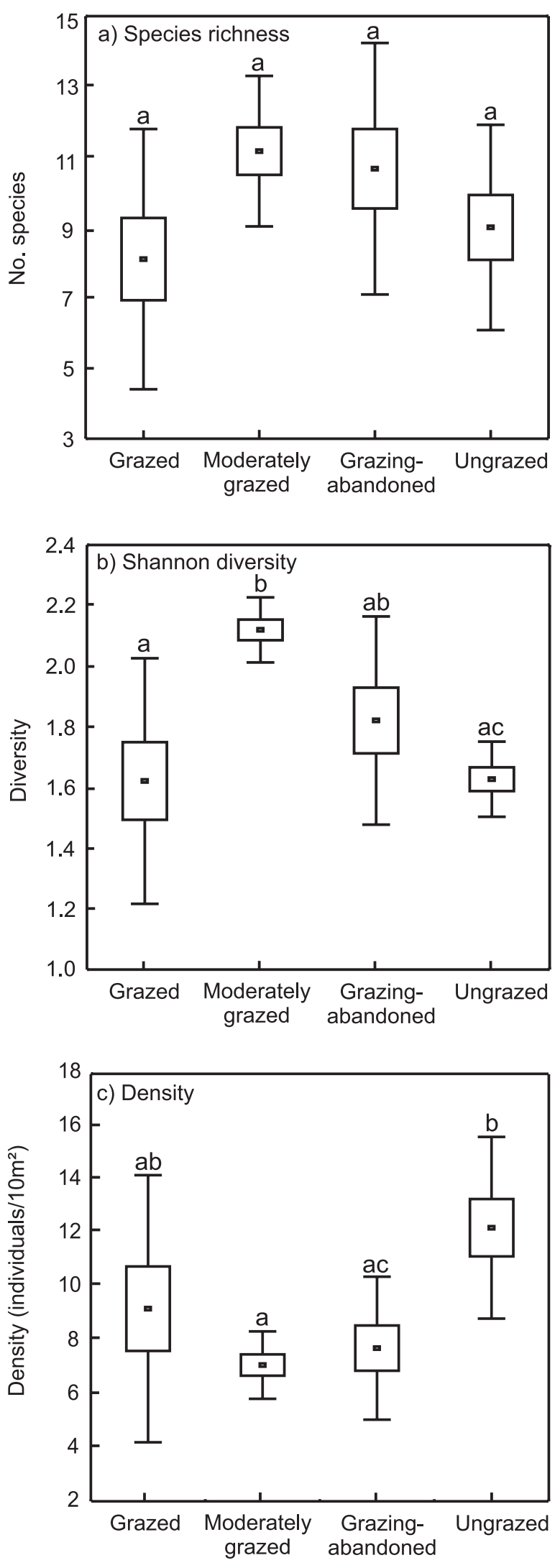

Fig. 2. Mean values (min-max and $\pm S E$ ) of main parameters of orthopteran assemblages under different grazing pressure. Significant $(\mathrm{p}<0.05)$ differences detected by Mann-Whitney U test are indicated by different letters. 


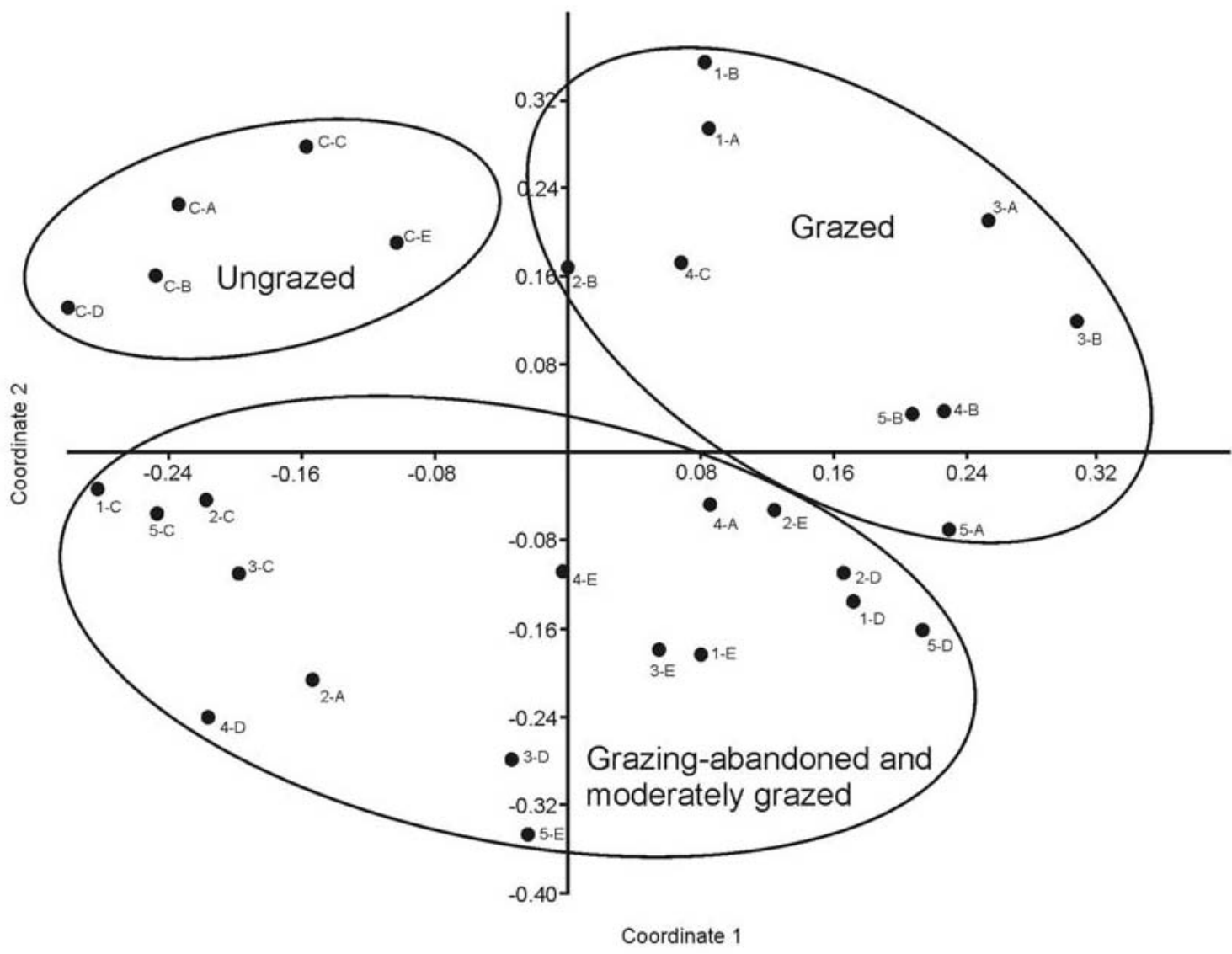

Fig. 3. PCoA ordination (sum of all eigenvalues: 20.008, similarity index: correlation) based on Orthoptera data. The different years are marked by A, B, C, D and E (A: 2012, B: 2013, C: 2014, D: 2015 and E: 2016; e.g. 1-A: site 1 in 2012, 2-B: site 2 in 2013, C-C: control site in 2014).

Table 1. Main vegetation characteristics of the sampling sites (mean values $( \pm \mathrm{SE})$ of the measured data in June, July and August).

\begin{tabular}{lcccc}
\hline & $\begin{array}{c}\text { Grazed } \\
\text { (June-August) }\end{array}$ & $\begin{array}{c}\text { Grazing-abandoned } \\
\text { (June-August) }\end{array}$ & $\begin{array}{c}\text { Moderately grazed } \\
\text { (June-August) }\end{array}$ & $\begin{array}{c}\text { Ungrazed } \\
\text { (June-August) }\end{array}$ \\
\hline Vegetation height $(\mathrm{cm})$ & $3.3 \pm 0.4$ & $11.7 \pm 1.3$ & $18.3 \pm 3.5$ & $26.0 \pm 1.8$ \\
Vegetation cover $(\%)$ & $44.0 \pm 4.8$ & $78.8 \pm 1.8$ & $82.5 \pm 1.1$ & $72.0 \pm 3.4$ \\
\hline
\end{tabular}

ones $\left(\mathrm{U}_{\mathrm{G}-\mathrm{MG}}=9, \mathrm{p}=0.026 ; \mathrm{U}_{\mathrm{G}-\mathrm{GA}}=15, \mathrm{p}=0.015\right)$ and the relative frequency of graminicol/pratinicol species was significantly lower on ungrazed sites than on moderately grazed sites $\left(\mathrm{U}_{\mathrm{MG}-\mathrm{UG}}=4, \mathrm{p}\right.$ $=0.050)$ (Fig. 5).

Effects of environmental parameters.-Based on the results of generalized linear models, total vegetation cover (VCOV), vegetation height $(\mathrm{VH})$ and percentage of bare soil (BSOIL) were found as significant predictors of the frequency of geophilic species and, parallel to this, the frequency of graminicol/pratinicol species (VCOV/Geo_freq: -0.0055; SE: 0.125; $\mathrm{p}=0.002$; VCOV/Gra_prat_ freq: 0.0055; SE: 0.018; $\mathrm{p}=0.002 ; \mathrm{VH} / \mathrm{Geo} \_$freq: -0.0097 ; SE: 0.003; $\mathrm{p}=0.012 ; \mathrm{VH} / \mathrm{Gra} \_$prat_freq: 0.0097; SE: 0.003; $\mathrm{p}=0.012$; BSOIL/Geo_freq: 0.0056; SE: 0.001; $\mathrm{p}=0.001$; BSOIL/Gra_prat_ freq: -0.0056 ; SE: $0.001 ; \mathrm{p}=0.001$ ). Total vegetation cover (VCOV) and vegetation height $(\mathrm{VH})$ (Table 1, Fig. 6) were negatively related to the frequency of geophilic species, while the percentage of bare soil (BSOIL) was positively related. The total vegetation cover (VCOV) and vegetation height $(\mathrm{VH})$ were positively related to the frequency of graminicol/pratinicol species, and the percentage of bare soil (BSOIL) was negatively related.

Three predictor variables contributed significantly to the CCA ordination. Relative frequency of geophilic species, such as Acrida ungarica, Acrotylus insubricus, Aiolopus thalassinus (Fabricius), Calliptamus barbarus, Calliptamus italicus (Linnaeus), Celes variabilis, Oedaleus decorus, and Oedipoda caerulescens, was positively correlated with a high percentage of bare soil (BSOIL) (Fig. 7). On the other hand, relative frequency of graminicol/pratinicol species, such as Gampsocleis glabra, Montana montana, Platycleis albopunctata (Goeze), Stenobothrus fischeri, and Stenobothrus lineatus (Panzer) was positively related to a high total cover of vegetation and vertically structured grasslands (Fig. 7).

\section{Discussion}

Grazing intensity or abandonment of grazing has a detrimental effect on the structure of orthopteran assemblages (Kruess and Tscharntke 2002, WallisDeVries et al. 2007, Eschen et al. 2012). 


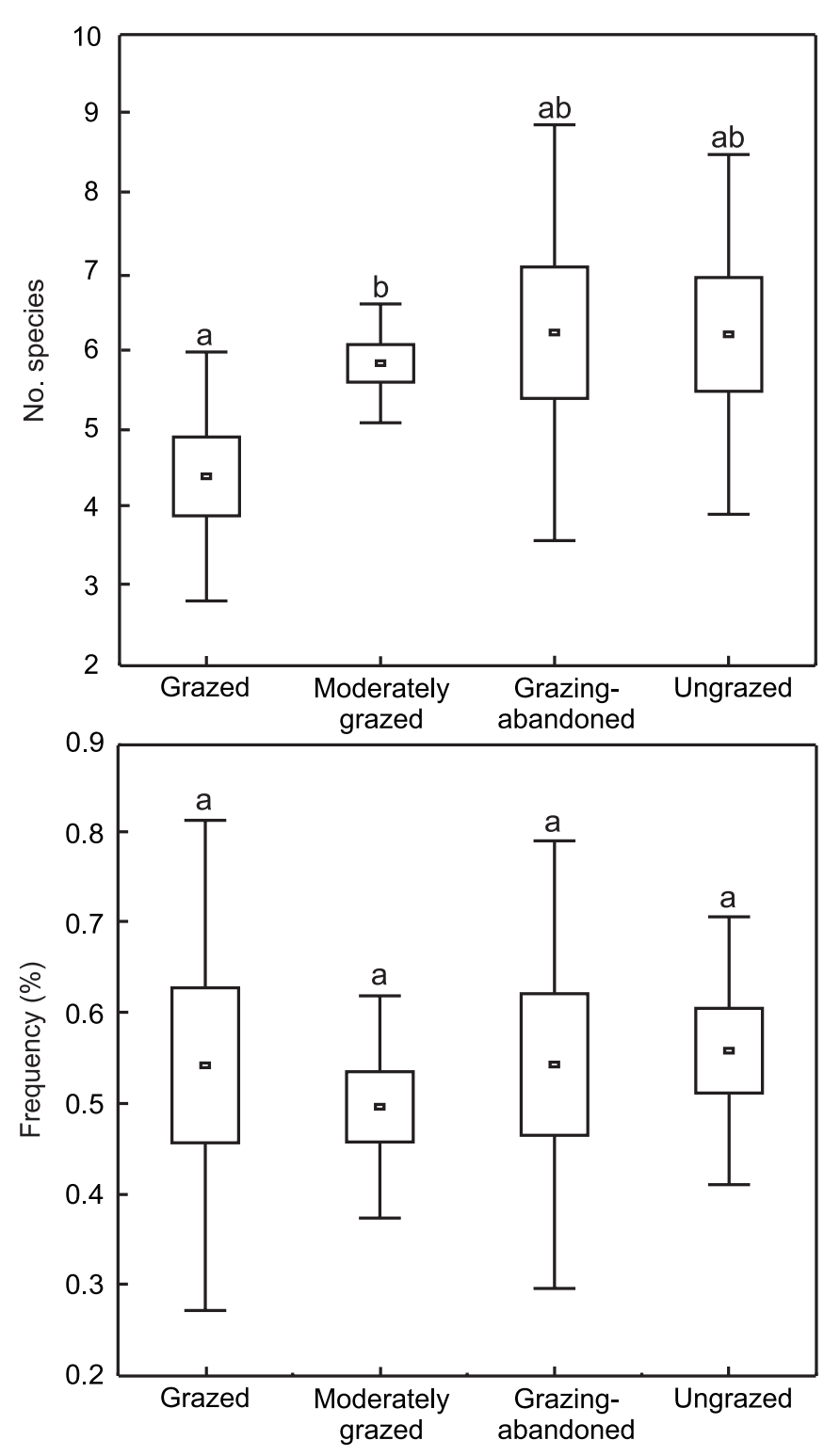

Fig. 4. Mean values (min-max and \pm SE) of species number and frequency of habitat specialist species under different grazing pressure. Significant $(\mathrm{p}<0.05)$ differences detected by Mann-Whitney $\mathrm{U}$ test are indicated by different letters.

Studied grasshopper assemblages of the Central-European sand grasslands showed the greatest diversity on patches affected by extensive grazing (Quinn and Walgenbach 1990, Enyedi et al. 2008). This result is similar to those of Batáry et al. (2007) and Fabriciusová et al. (2011) from other grassland types of the Carpathian Basin. In addition to the species with a positive correlation to open soil surfaces, these patches provide for the conservation of xero-thermophilic habitat specialists (Fonderflick et al. 2014) related to heterogeneous vegetation (Batáry et al. 2007) such as the European Red-Listed Gampsocleis glabra and Montana montana (Hochkirch et al. 2016). Extensive grazing therefore results in higher species richness of habitat specialist orthopterans in the moderately grazed patches than in grazed ones (Fig. 4). Overall density of the orthopteran assemblages
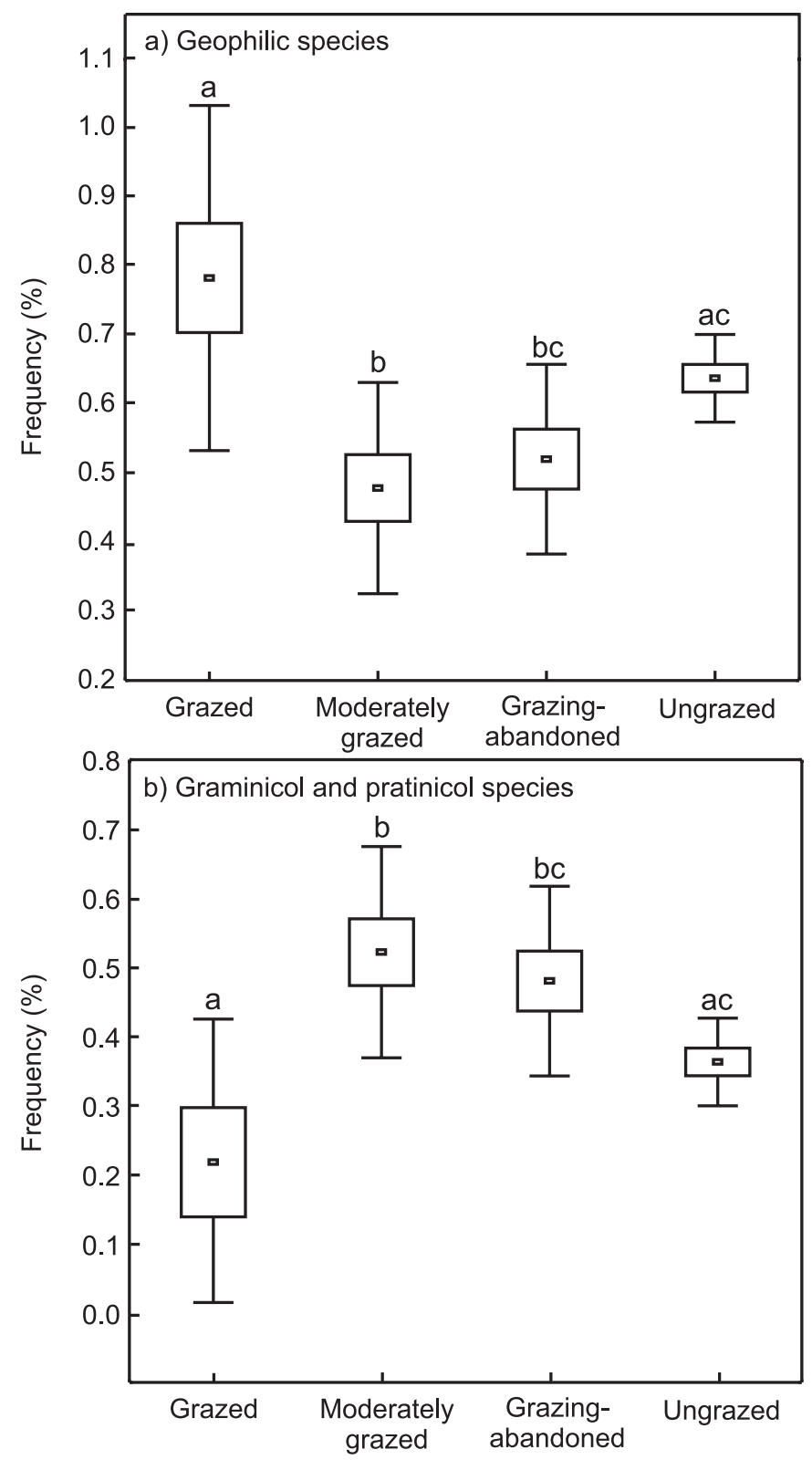

Fig. 5. Mean values (min-max and $\pm S E$ ) of relative frequency of geophilic and vegetation structure-dependent species under different grazing pressure. Significant $(\mathrm{p}<0.05)$ differences detected by Mann-Whitney $U$ test are indicated by different letters.

was high on several grazed patches. This is probably explained by the species-specific response of the orthopterans to grazing ( $\mathrm{O}^{\prime} \mathrm{Neill}$ et al. 2003, Jauregui et al. 2008). For example, Chorthippus biguttulus (Linnaeus) (Fonderflick et al. 2014) and Stenobothrus stigmaticus (Rambur) (Jauregui et al. 2008) reach high density in intensively grazed grasslands. In the present study, Acrida ungarica, Calliptamus barbarus and Oedaleus decorus have proved to be species preferring habitat-structure transformed by grazing. The latter species, according to their energy requirements (Fielding and Brusven 1995), reached much higher abundance on the grazed patches characterized by short vegetation and fragmented by open sandy surfaces, than on the grazing-abandoned habitats. The decline in prevalence of the geophilic lifestyle due to the abandonment of grazing (Fig. 

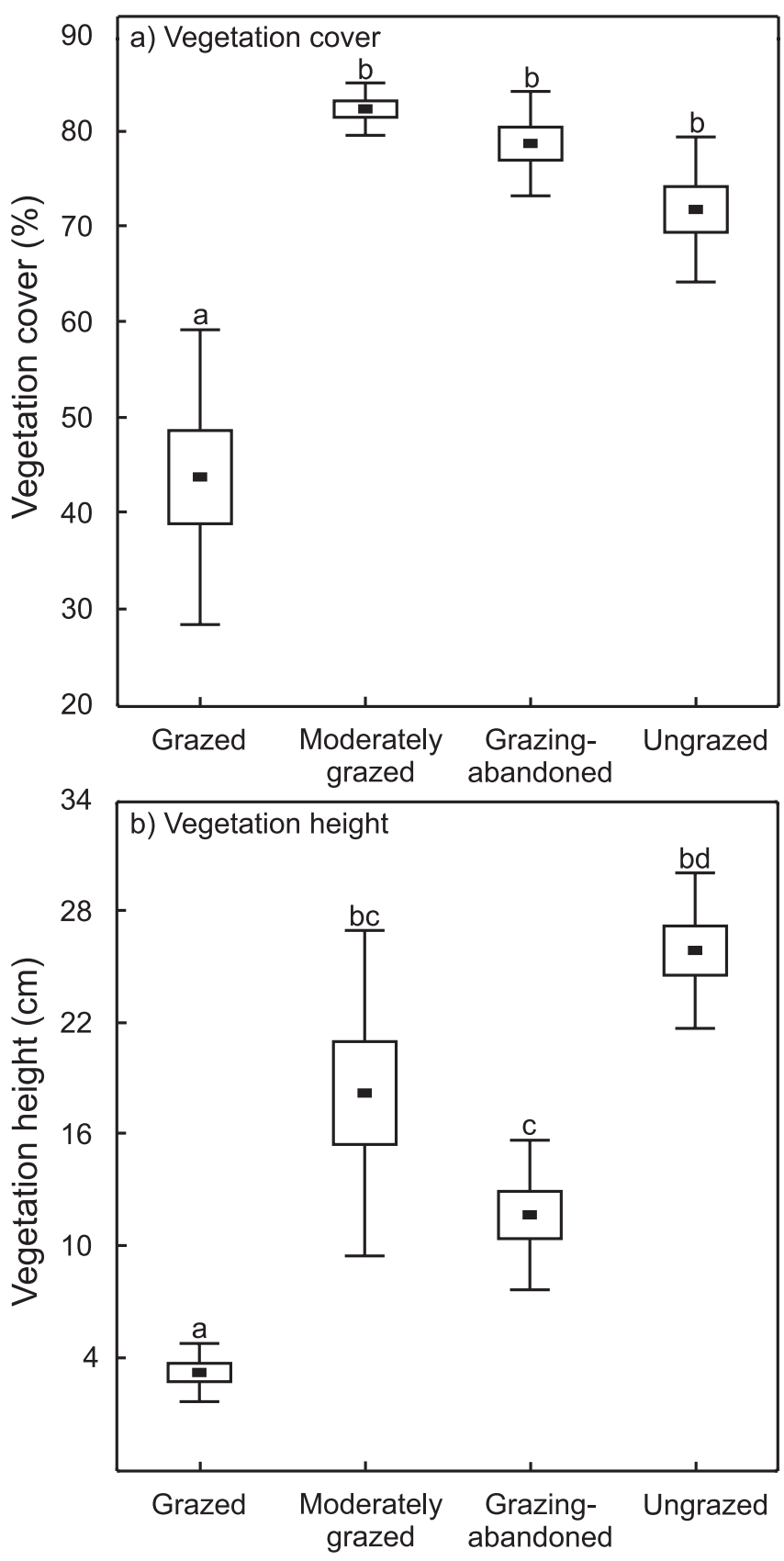

Fig. 6. Mean values (min-max and $\pm \mathrm{SE}$ ) of vegetation cover and vegetation height on the studied sites. Significant $(\mathrm{p}<0.05)$ differences detected by Mann-Whitney U test are indicated by different letters.

5) has also been proven by revealing a sharp difference between the habitat requirements of species related to open patches with short grasses and to closed patches with structured spatial composition (Fig. 7). The fact that the density of pratinicol and graminicol species, as an inverse trend, was significantly low until the abandonment of grazing, is explained by the fact that the vegetation structure was simplified due to the effect of grazing, which is unfavourable for pratinicol and graminicol species in terms of a nutritional base, microclimate, egg-laying possibilities and exposure to predators (Kruess and Tscharntke 2002, Gardiner and Haines 2008).

Following from the results and suggestions by Jerrentrup et al. (2014) and Joubert et al. (2016), the conservation of species rich- ness and diversity of the studied orthopteran assemblages can best be ensured by moderate grazing. The definition of moderate vs. extensive grazing is not possible in general, but only in relation to the given habitats. Jerrentrup et al. (2014) estimated that grazing intensity of $\sim 1$ Livestock Units/ha can still be considered moderate, resulting in habitat structure rich in microhabitats that ensure the presence of diverse orthopteran assemblages. However, the assemblages of dry steppe grasslands are more sensitive to grazing pressure. According to the results of Fonderflick et al. (2014), in the case of extensive grazing of dry steppe grasslands with sheep (0.24 Livestock Units/ha), the abundance of orthopterans is significantly higher in the ungrazed spots than in the post-grazed areas. According to Gardiner and Haines (2008), in the case of grazing by horses, reduction of intensity from 3.5 horse/ha to 2 horse/ ha can lead to an increase in the diversity and abundance of the orthopteran assemblage. The grasslands examined in the current study belong to the extremely low grass-producing habitats that are highly sensitive to treading. Thus, for the largest species richness, diversity and density of the local orthopteran assemblages, the extensive grazing system proposed by Máté (2014) should be used: 1) Grazing pressure should be set between 0.1-0.2 Livestock Units/ha; 2) Ungrazed patches should be left in the grasslands concerned each year. The desirable extent of the latter should be set as $10-50 \%$ of the grazed parcels. The greater the precipitation in a year, the smaller the percentage of the grasslands that has to be spared from grazing. Ungrazed areas should be designated at several isolated spots, and the grazed and ungrazed patches should be changed from year to year (on large pastures designated subareas should be used in every 1st, 3rd, 6th, and 10th year); 3 ) the land use must be controlled by the shepherd, ensuring the spread of the grazing animals.

In the examined habitats the annual grazing schedule is also important. In this respect, it has to be taken into account that the changing of vegetation structure affects orthopterans the most dramatically in the period when the number of adults in the assemblages is at its highest (August in Europe) (Fonderflick et al. 2014). During this period, the concentration of grazing on smaller, less natural, weedy patches is also acceptable in order to protect the valuable vegetation patches and their orthopteran assemblages. The conservation potential is strongly influenced by habitat conditions (Weiss et al. 2013). This is particularly true for habitats as sensitive as the Central European sandy steppes, where the grazing method should always be chosen by taking the weather conditions into consideration: during dry periods grazing must be moderated, or abandoned completely on the patches most sensitive to treading (Máté 2014).

On a global or historical scale, it is odd that we consider the development and use of different grazing systems for habitats that have been under continuous grazing pressure for hundreds or thousands of years, in order to preserve their biodiversity. This is not unjustified, however, given that from the end of the nineteenth century, in a significant part of Europe, habitats resulting from moderately disturbing and selective effects of extensive land management have disappeared, degraded and fragmented to the greatest extent (Bakker and Berendse 1999). As a result, the remaining habitat fragments became biodiversity hotspots (Steffan-Dewenter and Tscharntke 2002), the possible disappearance of which would be an irreversible loss. The preservation of the latter must therefore be given priority. As demonstrated by the present case study, changing the grazing patterns toward nature conservation-based land use can have positive results in terms of the protection of diverse orthopteran assemblages. However, for successful conserva- 


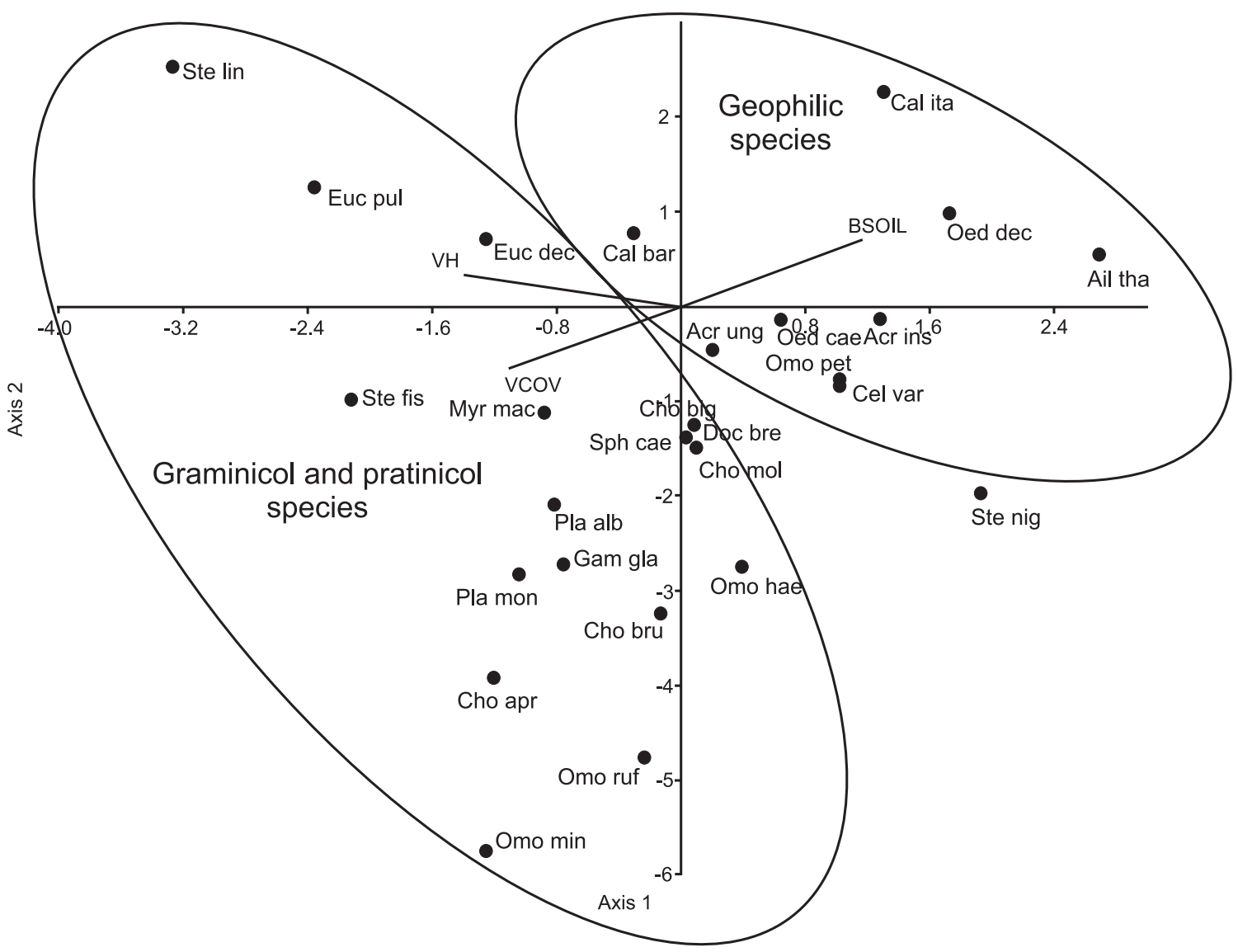

Fig. 7. CCA ordination based on Orthoptera data and environmental parameters (VCOV: total vegetation cover; BSOIL: percentage of bare soil; VH: height of the vegetation). Abbreviations of species names: Acr ins: Acrotylus insubricus; Acr ung: Acrida ungarica; Ail tha: Aiolopus thalassinus; Cal bar: Calliptamus barbarus; Cal ita: Calliptamus italicus; Cel var: Celes variabilis; Cho apr: Chorthippus apricarius; Cho big: Chorthippus biguttulus; Cho bru: Chorthippus brunneus; Cho mol: Chorthippus mollis; Doc bre: Dociostaurus brevicollis; Euc dec: Euchorthippus declivus; Euc pul: Euchorthippus pulvinatus; Gam gla: Gampsocleis glabra; Mon mon: Montana montana; Myr mac: Myrmeleotettix maculatus; Oed cae: Oedipoda caerulescens; Oed dec: Oedaleus decorus; Omo hae: Omocestus haemorrhoidalis; Omo min: Omocestus minutus; Omo pet: Omocestus petraeus; Omo ruf: Omocestus rufipes; Pla alb: Platycleis albopunctata; Sph cae: Sphingonotus caerulans; Ste fis: Stenobothrus fischeri; Ste lin: Stenobothrus lineatus; Ste nig: Stenobothrus nigromaculatus.

tion strategies for sensitive communities requiring moderate disturbance, it is important to conduct further, preferably long-term, studies on the response of orthopteran assemblages as bioindicators (Bazelet and Samways 2011) to the direct and indirect effects of grazing systems linked to fragmented habitats.

\section{Acknowledgements}

The author would like to express his gratitude to Csaba Szinetár and to Kiskunság National Park Directorate for the assistance during the research. I thank both reviewers for their remarks. Great thanks from the author go to Corinna S. Bazelet, managing editor of JOR, for her work with the manuscript and to Nancy Morris, for her help in repairing stylistic issues of the text.

\section{References}

Asner GP, Elmore AJ, Olander LP, Martin RE, Harris AT (2004) Grazing systems, ecosystems responses, and global change. Annual Review of Environment and Resources 29: 261-299. https://doi.org/10.1146/ annurev.energy.29.062403.102142
Bakker JP, Berendse F (1999) Constraints in the restoration of ecological diversity in grassland and heathland communities. Trends in Ecology and Evolution 14: 63-68. http://dx.doi.org/10.1016/S01695347(98)01544-4

Báldi A, Kisbenedek T (1997) Orthopteran assemblages as indicators of grassland naturalness in Hungary. Agriculture, Ecosystems and Environment 66: 121-129. https://doi.org/10.1016/S0167-8809(97)00068-6

Batáry P, Orci KM, Báldi A, Kleijn D, Kisbenedek T, Erdős S (2007) Effects of local and landscape scale and cattle grazing intensity on Orthoptera assemblages of the Hungarian Great Plain. Basic and Applied Ecology 8: 280-290. https://doi.org/10.1016/j.baae.2006.03.012

Bazelet CS, Samways MJ (2011) Identifying grasshopper bioindicators for habitat quality assessment of ecological networks. Ecological Indicators 11: 1259-1269. https://doi.org/10.1016/j.ecolind.2011.01.005

Carboni M, Dengler J, Mantilla-Contreras J, Venn S, Török P (2015) Conservation value, management and restoration of Europe's semi natural open landscapes. Haquetia 14: 5-17. https://doi.org/10.1515/ hacq-2015-0017

Cease AJ, Elser JJ, Ford CF, Hao S, Kang L, Harrison JF (2012) Heavy livestock grazing promotes locust outbreaks by lowering plant nitrogen content. Science 335: 467-469. https://doi.org/10.1126/science. 1214433 
Cigliano MM, Braun H, Eades DC, Otte D (2017) Orthoptera Species File. Version 5.0. http://Orthoptera.SpeciesFile.org

Connell JH (1978) Diversity in tropical rain forests and coral reefs. Science 199: 1302-1310.

Critchley CNR, Adamson HF, McLean BML, Davies OD (2008) Vegetation dynamics and livestock performance in system-scale studies of sheep and cattle grazing on degraded upland wet heath. Agriculture, Ecosystems and Environment 128: 59-67. https://doi.org/10.1016/j. agee.2008.05.002

Dolek M, Geyer A (2002) Conserving biodiversity on calcareous grasslands in the Franconian Jura by grazing: a comprehensive approach. Biological Conservation 104: 351-360. https://doi.org/10.1016/S00063207(01)00200-2

Dövényi Z (Ed.) (2010) Magyarország kistájainak katasztere. [Cadastre of the Hungarian Microregions.] MTA Földrajztudományi Kutatóintézet, Budapest, 876 pp.

Enyedi ZM, Ruprecht E, Deák M (2008) Long-term effects of the abandonment of grazing on steppe-like grasslands. Applied Vegetation Science 11: 55-62. https://doi.org/10.1111/j.1654-109X.2008.tb00204.X

Eschen R, Brook AJ, Maczey N, Peach WJ (2012) Effects of reduced grazing intensity on pasture vegetation and invertebrates. Agriculture, Ecosystems and Environment 151: 53-60. https://doi.org/10.1016/j. agee.2012.01.017

Fabriciusová V, Kaňuch P, Krištín A (2011) Response of Orthoptera assemblages to management of montane grasslands in the Western Carpathians. Biologia 66: 1127-1133. https://doi.org/10.2478/s11756011-0115-1

Fielding DJ, Brusven MA (1995) Grasshopper densities on grazed and ungrazed rangeland under drought conditions in southern Idaho. Great Basin Naturalist 55: 352-358. https://doi.org/10.2307/41712911

Fonderflick J, Besnard A, Beuret A, Dalmais M, Schatz B (2014) The impact of grazing management on Orthoptera abundance varies over the season in Mediterranean steppe-like grassland. Acta Oecologica 60: 7-16. https://doi.org/10.1016/j.actao.2014.07.001

Frisnyák S, Csüllög G, Tamás L (2015) A Kárpát-medence tájhasználata a 16-17. században [Landscape Use in the Carpathian Basin in the 1617th centuries.] Történeti földrajzi közlemények 3: 1-12.

Gardiner T, Haines K (2008) Intensive grazing by horses detrimentally affects orthopteran assemblages in floodplain grassland along the Mardyke River Valley, Essex, England. Conservation Evidence 5: 38-44.

Gardiner T, Pye M, Field R, Hill J (2002) The influence of sward height and vegetation composition in determining the habitat preferences of three Chorthippus species (Orthoptera: Acrididae) in Chelmsford, Essex, UK. Journal of Orthoptera Research 11: 207-213. https://doi. org/10.1665/1082-6467(2002)011[0207:TIOSHA]2.0.CO;2

Hammer $\varnothing$, Harper DAT, Ryan PD (2001) PAST: Paleontological Statistics Software Package for Education and Data Analysis. Palaeontologia Electronica 4: 1-9.

Harz K (1969) Die Orthopteren Europas / The Orthoptera of Europe I. Series Ent. 5, The Hague, 749 pp.

Harz K (1975) Die Orthopteren Europas / The Orthoptera of Europe II. Series Ent. 11, The Hague, 939 pp.

Hochkirch A, Nieto A, García Criado M, Cálix M, Braud Y, Buzzetti FM, Chobanov D, Odé B, Presa Asensio JJ, Willemse L, Zuna-Kratky T, Barranco Vega P, Bushell M, Clemente ME, Correas JR, Dusoulier F, Ferreira S, Fontana P, García MD, Heller K-G, Iorgu IȘ, Ivković S, Kati V, Kleukers R, Krištín A, Lemonnier-Darcemont M, Lemos P, Massa B, Monnerat C, Papapavlou KP, Prunier F, Pushkar T, Roesti C, Rutschmann F, Şirin D, Skejo J, Szövényi G, Tzirkalli E, Vedenina V, Barat Domenech J, Barros F, Cordero Tapia PJ, Defaut B, Fartmann T, Gomboc S, Gutiérrez-Rodríguez J, Holuša J, Illich I, Karjalainen S, Kočárek P, Korsunovskaya O, Liana A, López H, Morin D, Olmo-Vidal JM, Puskás G, Savitsky V, Stalling T, Tumbrinck J (2016) European Red List of Grasshoppers, Crickets and Bush-crickets. Luxembourg: Publications Office of the European Union, 95 pp. https://doi. org/10.2779/60944

Ingrisch S, Köhler G (1998) Die Heuschrecken Mitteleuropas. Die Neue Brehm-Bücherei Bd. 629, Westarp Wissenschaften, Magdeburg.
Jauregui BM, Rosa-Garcia R, Garcia U, WallisDeVries MF, Osoro K, Celay R (2008) Effects of stocking density and breed of goats on vegetation and grasshopper occurrence in heathlands. Agriculture, Ecosystems and Environment 123: 219-224. https://doi.org/10.1016/j.agee.2007.06.004

Jepson-Innes K, Bock CE (1989) Response of grasshoppers (Orthoptera: Acrididae) to livestock grazing in southeastern Arizona: Differences between seasonal and subfamily. Oecologia 78: 430-431. https://doi. org/10.1007/BF00379121

Jerrentrup JS, Wrage-Monnig N, Rover K-U, Isselstein J (2014) Grazing intensity affects insect diversity via sward structure and heterogeneity in a long-term experiment. Journal of Applied Ecology 51: 968-977. https://doi.org/10.1111/1365-2664.12244

Joubert L, Pryke JS, Samways MJ (2016) Positive effects of burning and cattle grazing on grasshopper diversity. Insect Conservation and Diversity 9: 290-301. https://doi.org/10.1111/icad.12166

Krištín A, Kanuch P, Fabriciusova V, Gavlas V (2009) Responses on habitat and global change of some Mediterranean orthopteran species occurring in blown sands in Central Europe - 10th International Congress of Orthopterology, Metaleptea, Special Conference Issue, Orthopterists' Society and Akdeniz University, 42.

Kruess A, Tscharntke T (2002) Contrasting responses of plant and insect diversity to variation in grazing intensity. Biological Conservation 106: 293-302. https://doi.org/10.1046/j.1523-1739.2002.01334.x

Kun A (1998) Száraz gyepek Magyarországon. [Dry grasslands in Hungary.] In: Kiszel V (Ed.) Természetvédelem területhasználók számára. [Nature protection for landusers.] Göncöl Alapítvány, Vác, 65-90.

Magurran A E (2004) Measuring biological diversity. Blackwell, Oxford.

Máté A (2014) 6260 Pannon homoki gyepek. [6260 Pannonic sand steppes] In: Haraszthy L (Ed) Natura 2000 fajok és élőhelyek Magyarországon [Natura 2000 species and habitats in Hungary], Pro Vértes Közalapítvány, Csákvár, 817-823.

Matus G, Tóthmérész B, Papp M (2003) Restoration prospects of abandoned species-rich sandy grassland in Hungary. Applied Vegetation Science 6: 169-178. https://doi.org/10.1111/j.1654-109X.2003. tb00577.x

Metera E, Sakowski T, Słoniewski K, Romanowicz B (2010) Grazing as a tool to maintain biodiversity of grassland-a review. Animal Science Papers and Reports 28: 315-334.

Molnár Zs (Ed.) (2003) A Kiskunság száraz homoki növényzete. [Dry sandy vegetation of Kiskunság.] TermészetBúvÁR Alapítvány Kiadó, Budapest, $159 \mathrm{pp}$.

Molnár Zs, Fekete G, Biró M, Kun A (2008) A Duna-Tisza közi homoki sztyepprétek történeti tájökológiai jellemzése. [Landscape historical ecological description of sandy steppe grasslands of plateau between the Danube and Tisza rivers.] In: Kröel-Dulay Gy, Kalapos T, Mojzes A (Eds) Talaj-vegetáció-klíma kölcsönhatások. [Soil-vegetation-climate interactions.] MTA ÖBKI, Vácrátót, 39-56.

O'Neill KM, Olson BE, Rolston MG, Wallander R, Larson DP, Seibert CE (2003) Effects of livestock grazing on rangeland grasshopper (Orthoptera: Acrididae) abundance. Agriculture, Ecosystems and Environment 97: 51-64. https://doi.org/10.1016/S0167-8809(03)00136-1

Onsager JA (2000) Suppression of grasshoppers in the Great Plains through grazing management. Journal of Range Management 53: 592-602. https://doi.org/10.2307/4003152

Pickett STA, Parker T, Fiedler P (1992) The new paradigm in ecology: implications for conservation biology above the species level. In: Fiedler P, Subodh KJ (Eds) Conservation Biology. Chapman and Hall, New York and London, 65-88.

Prendini L, Theron L-J, Merwe KD, Owen-Smith N (1996) Abundance and guild structure of grasshoppers (Orthoptera: Acridoidea) in communally grazed and protected savanna. South African Journal of Zoology 31: 120-130. https://doi.org/10.1080/02541858.1996.11448403

Quinn M, Walgenbach DD (1990) Influence of grazing history on the community structure of grasshoppers of a mixed-grass prairie. Environmental Entomology 19: 1756-1766. https://doi.org/10.1093/ee/19.6.1756

Rácz I (1998) Biogeographical survey of the Orthoptera Fauna in Central Part of the Carpathian Basin (Hungary): Fauna types and community types. Articulata 13: 53-69. 
Samways MJ (1997) Conservation biology of Orthoptera. In: Gangwere SK, Muralirangan MC, Muralirangan M (Eds) Bionomics of Grasshoppers, Katydids and their Kin. Wallingford, CAB International, 481-496.

Sedláková I, Fiala K (2001) Ecological degradation of alluvial meadows due to expanding Calamagrostis epigeios. Ekológia (Bratislava) 20: 226-333.

Steffan-Dewenter I, Tscharntke T (2002) Insect communities and biotic interactions on fragmented calcareous grasslands-a mini review. Biological Conservation 104: 275-284. https://doi.org/10.1016/S0006-3207(01)00192-6

Török P, Hölzel N, van Diggelen R, Tischew S (2016) Grazing in European open landscapes: How to reconcile sustainable land management and biodiversity conservation? Agriculture, Ecosystems and Environment 234: 1-4. https://doi.org/10.1016/j.agee.2016.06.012

Uvarov BP (1977) Grasshoppers and Locusts, Vol. II. Centre for Overseas Pest Research, London.

Varga Z (1997) Trockenrasen im pannonischen Raum: Zusammenhang der physiognomischen Struktur und der florischtischen Komposition mit den Insektenzönosen. Phytocoenologia 27: 509-571.

WallisDeVries MF, Parkinson AE, Dulphy JP, Sayer M, Diana E (2007) Effects of livestock breed and grazing intensity on biodiversity and production in grazing systems. 4. Effects on animal diversity. Grass and Forage Science 62: 185-197. https://doi.org/10.1111/j.1365-2494.2007.00568.x
Weiss N, Zucchi H, Hochkirch A (2013) The effects of grassland management and aspect on Orthoptera diversity and abundance: Site conditions are as important as management. Biodiversity and Conservation 22: 2167-2178. https://doi.org/10.1007/s10531-012-0398-8

Welch JL, Redak R, Kondratieff BC (1991) Effect of cattle grazing on the density and species of grasshoppers (Orthoptera: Acrididae) of the Central Great Plains experimental range, Colorado: a reassessment after two decades. Journal of the Kansas Entomological Society 64: 337-343.

White EG (1975) A survey and assessment of grasshoppers as herbivores in the South Island alpine tussock grasslands of New Zealand. New Zealand Journal of Agricultural Research 18: 73-85. https://doi.org/1 $0.1080 / 00288233.1975 .10430390$

Wingerden WKRE, Musters JCM, Kleukers RMJC, Bongers W, van Biezen JB (1991) The influence of cattle grazing intensity on grasshopper abundance (Orthoptera: Acrididae). Proceedings of the Section Experimental and Applied Entomology 2: 28-34.

Zhu H, Wang D, Guo Q, Liu J, Wang L (2015) Interactive effects of large herbivores and plant diversity on insect abundance in a meadow steppe in China. Agriculture, Ecosystems and Environment 212: 245-252. https://doi.org/10.1016/j.agee.2015.07.008

\section{Appendix 1}

Species composition and abundance of the pooled samples of different grazing pressure (LF: life form; EF: ecotype form; G: grazed, MG: moderately grazed, GA: grazing-abandoned, UG: ungrazed; arbu: arbusticol; geo: geophilic; gra: graminicol; pra: pratinicol; ps: psammophilic; psps: pseudo-psammophilic; mes: mesophilic; m-ther: moderately-thermophilic; ther: thermophilic)

\begin{tabular}{|c|c|c|c|c|c|c|}
\hline Taxon & LF & EF & G & MG & GA & UG \\
\hline \multicolumn{7}{|l|}{ Caelifera } \\
\hline \multicolumn{7}{|l|}{ Acridoidea } \\
\hline \multicolumn{7}{|l|}{ Acridomorpha } \\
\hline \multicolumn{7}{|l|}{ Acridinae } \\
\hline Acrida ungarica (Herbst, 1786) & psps & ther & 172 & 186 & 77 & 79 \\
\hline Calliptamus italicus (Linnaeus, 1758) & gra & ther & 6 & 0 & 4 & 0 \\
\hline \multicolumn{7}{|l|}{ Gomphocerinae } \\
\hline Euchorthippus declivus (Brisout de Barneville, 1848) & gra & ther & 18 & 89 & 60 & 135 \\
\hline Euchorthippus pulvinatus (Fischer de Waldheim, 1846) & gra & ther & 0 & 8 & 18 & 28 \\
\hline Euthystira brachyptera (Ocskay, 1826) & pra & mes & 0 & 0 & 2 & 0 \\
\hline Chorthippus brunneus (Thunberg, 1815) & pra & m-ther & 10 & 17 & 11 & 1 \\
\hline Chorthippus dichrous (Eversmann, 1859) & pra & mes & 0 & 0 & 6 & 0 \\
\hline Chorthippus mollis (Charpentier, 1825) & pra & mes & 11 & 11 & 13 & 0 \\
\hline Myrmeleotettix maculatus (Thunberg, 1815) & gra & ther & 22 & 99 & 37 & 27 \\
\hline Pseudochorthippus parallelus (Zetterstedt, 1821) & pra & mes & 3 & 0 & 0 & 0 \\
\hline Omocestus haemorrhoidalis (Charpentier, 1825) & pra & ther & 5 & 0 & 1 & 0 \\
\hline Omocestus minutus (Brullé, 1832) & psps & ther & 0 & 4 & 0 & 0 \\
\hline Omocestus petraeus (Brisout de Barneville, 1856) & gra & ther & 30 & 16 & 4 & 2 \\
\hline Omocestus rufipes (Zetterstedt, 1821) & pra & mes & 1 & 3 & 1 & 0 \\
\hline Stenobothrus fischeri (Eversmann, 1848) & pra & ther & 0 & 9 & 33 & 2 \\
\hline
\end{tabular}




\begin{tabular}{|c|c|c|c|c|c|c|}
\hline Acrotylus insubricus (Scopoli, 1786) & ps & ther & 30 & 5 & 2 & 6 \\
\hline Aiolopus thalassinus (Fabricius, 1781) & gra & m-ther & 21 & 2 & 0 & 0 \\
\hline Celes variabilis (Pallas, 1771) & gra & ther & 4 & 0 & 0 & 1 \\
\hline Oedaleus decorus (Germar, 1826) & psps & ther & 213 & 18 & 21 & 27 \\
\hline Sphingonotus caerulans (Linnaeus, 1767) & psps & ther & 2 & 1 & 0 & 1 \\
\hline \multicolumn{7}{|l|}{ Pezotettiginae } \\
\hline Pezotettix giornae (Rossi, 1794) & gra & ther & 1 & 0 & 0 & 0 \\
\hline \multicolumn{7}{|l|}{ Ensifera } \\
\hline \multicolumn{7}{|l|}{ Tettigonioidea } \\
\hline Platycleis affinis Fieber, 1853 & psps & ther & 0 & 0 & 2 & 0 \\
\hline Platycleis albopunctata (Goeze, 1778) & pra & ther & 1 & 3 & 1 & 1 \\
\hline \multicolumn{7}{|l|}{ Phaneropteridae } \\
\hline \multicolumn{7}{|l|}{ Phaneropterinae } \\
\hline Leptophyes albovittata (Kollar, 1833) & arbu & ther & 0 & 0 & 0 & 2 \\
\hline
\end{tabular}

